\title{
Geotechnical Risk Identification: Case Study of Flexible Retaining Wall Installation
}

\author{
Danute SLIZYTE ${ }^{1}$ \\ Natalija LEPKOVA ${ }^{2}$ \\ Rimantas MACKEVICIUS ${ }^{3}$
}

\begin{abstract}
Analysis of the scientific literature has demonstrated that the risk of collapse or deformations of flexible retaining walls has not been the object of in-depth examination so far. The article presents an analysis of the main geotechnical risks, focusing on the installation of flexible retaining walls according to analysis by construction participants and their experiences. A case study was conducted to identify the risks of flexible retaining walls. In order to determine the risks of installation of flexible retaining walls, the authors of the article employed a face-to-face interview approach. Investigation of the data obtained during the face-to-face interview was based on brainstorming and the cause and effect diagram: five professionals who had monitored most of the risks were selected with the help of the faceto-face interview. The results of the investigation showed, that for specific and complicated projects the team of professionals should be composed of specialists from different fields of construction. Additionally, the respondents agreed with the opinion that the greatest loss in the given situation would be caused by a breakdown in the pressure pipe and pollution of the natural environment by wastewater. The novelty of the article on investigating the possibilities for identifying the risk of installation of flexible retaining walls and on suggesting risk identification steps.
\end{abstract}

Keywords: Flexible retaining wall, technical risk, cause and effect diagram.

Note:

- This paper has been received on September 12, 2018 and accepted for publication by the Editorial Board on April 24, 2019.

- Discussions on this paper will be accepted by September 30, 2020.

- https://dx.doi.org/10.18400/tekderg.459316

1 Department of Reinforced Concrete Structures and Geotechnics, Vilnius Gediminas Technical University, Vilnius, Lithuania -danute.slizyte@vgtu.lt- https://orcid.org/0000-0002-1220-7485

2 Department of Construction Management and Real Estate, Vilnius Gediminas Technical University, Vilnius, Lithuania - natalija.lepkova@vgtu.lt - https://orcid.org/0000-0002-9760-1747

3 Department of Reinforced Concrete Structures and Geotechnics, Vilnius Gediminas Technical University, Vilnius, Lithuania - rimantas.mackevicius@vgtu.lt -https://orcid.org/0000-0002-5643-1147 


\section{INTRODUCTION}

The article analyzes risk identification when installing flexible retaining walls. The article considers this problem, taking into account that not all risks are always assessed within the process of installing flexible retaining walls, which may result in collapse or deformations.

To determine and analyze risk, the concept has to be defined. Risk considers the probability of an event occurring and the consequences of the event, should it occur [1]. Emerging risk can be defined as the likelihood of loss, that is, the probability that a certain consequence will occur in a specific time and space under specified or insufficiently specified conditions [2]. This article adopts the definition of risk as the 'effect of uncertainties on objectives' given by ISO 31000:2009 [3]. The definition provides that uncertainties include events (that may or may not happen) and are caused by ambiguity or lack of information. It also includes both negative and positive impacts on objectives [3]. The article reports only negative effects.

Geotechnical risk has been analyzed in a number of scientific articles. Duncan [4] investigated safety and reliability in geotechnical engineering. Special attention was paid to uncertainty about the factors involved in safety against sliding. As an example, the stability of a cantilever retaining wall with silty sand backfill was analysed. Gibson [5] explored and compared four probabilistic methods for slope analysis and design. Brown [6] reviewed risk assessment and management practice in underground rock engineering. Swannell et al. [7] analysed the geotechnical risk management approach to boring machines tunnelling under squeezing ground conditions. Lacasse [1] showed how the concepts of hazard, risk, and reliability could help with making more secure decisions. The article shows examples of calculation taken from a wide range of geotechnical problems, including the hazard and risk of collapse related to railway traffic, mine slopes, and soil exploration. Mishra et al. [8] analysed tools for geotechnical real-time risk assessment and management and proposed a geotechnical risk management workflow diagram of intelligent deep mines. Xia et al. [9] focused on the issue of model uncertainty and differences in risk consciousness with different decision-makers in tunnel and underground engineering and proposed a risk decision model based on sensitivity analysis and tolerance cost, which can improve decision-making efficiency. Haddad et al. [10] performed a study based on the failure and stability of gravity retaining walls, which can be categorized into three different modes of failure in sliding, overturning, and foundation-bearing capacity. They introduced a relatively simple method of probabilistic analysis of the dimensions of gravity retaining walls which might lead to a more accurate understanding of failure. Risk management in the architecture, engineering, and construction industries remains a global issue. Lack of adequate risk management may cause difficulties in implementing the objectives of a project and negatively affect spatial planning and urban spatial design in the future. Yang et al. [11] analysed risk management in the field of health and safety using Building Information Modelling (BIM) and other BIM-related technologies. Li et al. [12] analysed site selection for underground petroleum storage. To reduce construction risk and cost during the construction of underground petroleum storage, they proposed a new site selection model for large underground petroleum storage based on the analytic hierarchy process (AHP) method and ideal point theory. Xue at al. [13] analysed rockburst hazard, which is an important issue affecting safe production at coal mines in China. They paid attention to the influence of the backfilling roadway driving sequence on coal pillar stability. Ahmasi et al. [14] presented a comprehensive framework to manage the main risk events of highway construction projects within three stages: (1) identification of 
potential risks; (2) assessment and prioritization of identified risks based on fuzzy FMEA; (3) identification of appropriate response. Authors suggested the new expert system for identifying an appropriate risk response strategy for a risk event based on risk factor, control number and risk allocation. The proposed methodology is demonstrated for management of risk events in a construction project of Bijar-Zanjan highway in Iran. Valipour et al. [15] applied hybrid SWARA (Step-wise Weight Assessment Ratio Analysis) -COPRAS (COmplexPRoportionalASsessment) method for risk assessment in deep foundation excavation project through introducing new criteria for risk assessment. A case study of deep foundation excavation in Shiraz (Iran) was presented. The results have shown that the risks involving construction safety, unfavourable geological conditions, shortage of managerial experience, incomplete emergency plan and subsidence of ground are the most significant risks excavation projects in Shiraz.

To sum up, the risk of collapse or deformations of flexible retaining walls has not been widely examined.

This paper aims to identify the most common risks of installing flexible retaining walls. The analysis performed involves the face-to-face interview approach, brainstorming, and a cause and effect diagram. The article discusses a specific case of installing flexible retaining walls. This case study has been selected with reference to the results of the face-to-face interviews, showing that the parties involved in construction most frequently fail to assess the risk of installing the flexible retaining wall, which causes some problems in geotechnical applications in Lithuania. Identification of risks is important for risk analysis in order to reduce the number of emergencies. The face-to-face interview approach and the brainstorming method were chosen for analysis, as the knowledge and experience of experts in the field of installing flexible retaining walls allow a more thorough identification of possible risks. The major finding of the face-to-face interview approach was that the greatest loss is caused by breakdown in the pressure pipe. When analysing the case of installing the flexible retaining wall using the cause and effect diagram, all possible risks leading to the breakdown in the pipe are shown graphically.

The novelty of this article is investigating the identification of possible risks when installing flexible retaining walls and suggests risk identification steps in the risk management flow of the flexible retaining wall installation process.

The structure of the article is built as follows. Section 2 analyses geotechnical risks. The authors of the article present the case study and risk identification by applying the face-toface interview approach in Section 3. Having analysed the data obtained during the face-toface interview and clarifying the possible causes of breakdown in the pipe, brainstorming and the cause and effect diagram were used. Section 4 deals with risk identification in the risk management flow of the flexible retaining wall.

\section{GEOTECHNICAL RISK IDENTIFICATION}

Risk identification is very important in the risk management cycle. Once the risk has been identified, a decision has to be made regarding whether to take the risk if it is acceptable or to make some changes to reduce it if it is unacceptable. 
To identify risk, the Swedish Geotechnical Society (SGF) [16] recommends employing methods for detecting hazards and considering possibilities. When opting for techniques and organizing a risk management team, one has to adhere to the following principles:

Risk identification is considered to be an engineering task:

- anyone who may be of benefit to the work should be engaged in it;

- the goals of the project have to be considered first;

- a unified approach should prevail, and therefore all aspects of the project have to be studied;

- necessary information should be collected;

- both hazards and consequences have to be investigated and distinguished from each other;

- risk should be analysed without emotions;

- there should be concentration on risk rather than on solving related problems.

The result should be documented so that it can be used for the entire project.

The geotechnical risk of the project is a part of the risk of a construction project and is frequently one of the most controversial parts of the technical risks. 'Geotechnical risk - is the risk to buildings and construction work created by the site ground conditions' [17]. However, this is only one of many risks that are specific to geotechnical projects. Table 1 presents the specific risks and hazards of geotechnical projects. In general understanding, a hazard is something that can cause harm, e.g. electricity, chemicals, working up a ladder, noise, stress, etc. A risk is the chance, high or low, that any hazard will actually cause somebody harm. The geotechnical hazard can be named as building collapse, landslides and etc.

Table 1 - Specific risks and hazards of geotechnical projects (adapted by authors from Baynes' [18]).

\begin{tabular}{|c|c|c|}
\hline \multicolumn{2}{|c|}{ Type of geotechnical risk } & Hazard \\
\hline \multicolumn{2}{|c|}{ Project management } & Poor management of the entire geotechnical process \\
\hline \multicolumn{2}{|c|}{ Contractual } & $\begin{array}{c}\text { Poor management of site investigation and contractor } \\
\text { documentation }\end{array}$ \\
\hline \multirow{4}{*}{ Technical } & Analytical & $\begin{array}{l}\text { Unreasonable analytical model selected } \\
\text { Nonconformity of the structural scheme with design drawings } \\
\text { Nonconformity of the structural scheme with construction stages; } \\
\text { technological effects are not assessed }\end{array}$ \\
\hline & Properties & Unreasonable design values selected \\
\hline & Geological & $\begin{array}{c}\text { Inherently hazardous ground conditions } \\
\text { Unforeseen ground conditions }\end{array}$ \\
\hline & Construction & $\begin{array}{l}\text { Invalid construction type selected } \\
\text { Invalid technology selected }\end{array}$ \\
\hline
\end{tabular}


Based on the experience gained in the field of designing and constructing geotechnical objects, the authors of the article propose five categories for analysing geotechnical risks, as depicted in Figure 1: water, soil, seismology, surrounding buildings and structures, and technological processes used during construction.

The first three types of risks are natural and most uncertain.

The risk of breakdown of the structure(Figure 1) took into account geotechnical research, design, and Eurocodes and standards for specific geotechnical works.

The analysis of water level and its variations in terms of time shows that the groundwater level is not constant in nature and is subject to various factors such as seasonal changes, floods, tides, and so on. Frequently, the maximum possible rise in groundwater is calculated according to standardized diagrams that may not meet local conditions.

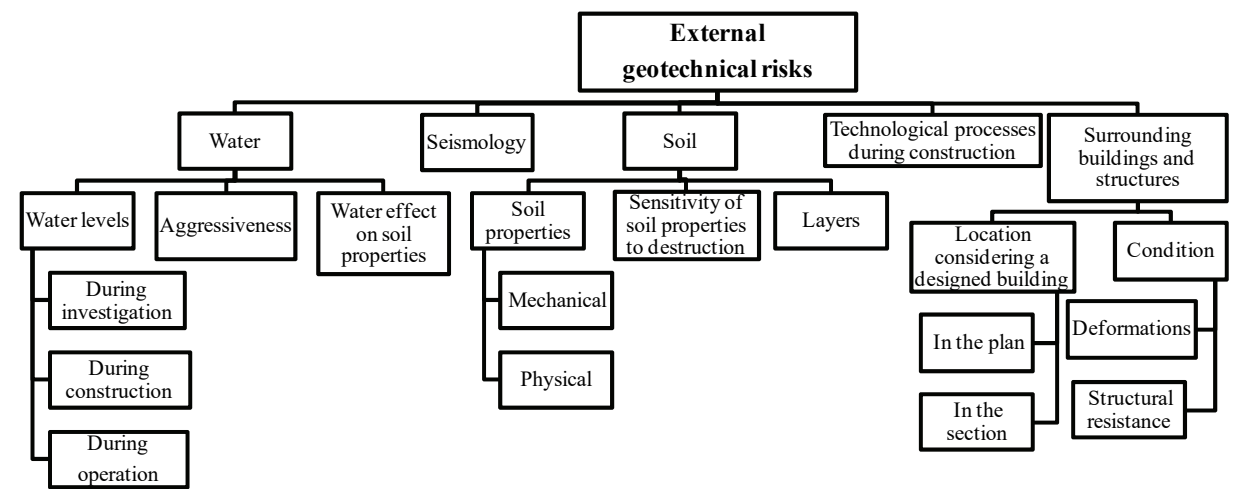

Figure 1 - External geotechnical risks

The following variations in water level may occur during construction:

- blocking the natural flow of water will result in a rise;

- the water flow may be artificially decreased if it interferes with construction processes.

Variations in soil moisture change the physical and mechanical properties of the soil more or less, which has a direct impact on the foundation works.

The soil is a naturally occurring dispersion substance whose properties are subject to the processes and conditions of formation, conditions of the study, and variations in those conditions. During testing, the mechanical and physical properties of the soil are determined by employing field (in situ) and laboratory methods. However, it should be noted that the test results largely depend on the qualifications and diligence of the staff involved in the investigation. Any inaccuracies in taking, transporting, preparing, and testing a specimen under laboratory conditions may cause serious distortion of the results. Thus, geotechnical studies often use accumulated information about the properties of similar soils and compare the findings with the results obtained. When in doubt, such results should be verified by additional testing. Attention should be drawn to the fact that soil properties are determined 
only at separate points of the soil matter. Hence, it is important that attention is paid to the selection of representative specimens when describing the characteristics of a single layer.

Variations in the characteristics of soil exposed to the effects of cold or mechanical or dynamic factors are accepted as one of the soil properties. Therefore, soil properties described -in the geotechnical report can only be applied on the condition that the structure of the soil will not be destroyed during construction and afterwards.

Soil characteristics appear to be one of the greatest sources of risk (see Table 2). Information on the layout of soil layers during engineering geological explorations and the preparation of a geotechnical report is limited. The placement of layers is directly investigated in separate places in the construction site by drilling, and information can be indirectly obtained through the Cone Penetration Test (CPT), Standard Penetration Test (SPT), or other methods. Only at tested points are the soil boundaries and type known. Between the tested points, only assumptions can be made. Therefore, only at the time of construction, when excavating the foundation pit, is it possible to verify whether the soil and the depth of the soil conform to the geotechnical report.

Table 2 - Sources of foundation-related risk in construction [17].

\begin{tabular}{lc}
\hline Risks related to & \% \\
\hline Soil boundaries & 22 \\
Soil properties & 20 \\
Groundwater & 13 \\
Contamination & 11 \\
Obstructions & 10 \\
Site investigation & 9 \\
Services & 6 \\
Detailed design & 5 \\
Other & 4 \\
\hline
\end{tabular}

The seismic effect on the specific construction site cannot be measured. This is the most uncertain geotechnical external effect. Designing seismic districts is one of the greatest risks, and the assessment of these risks may lead to fundamental changes in geotechnical solutions. This effect is strictly regulated by separate normative standards.

For the rest of the risks related to the environment, the size of uncertainties greatly depends on the ability to collect information about the surrounding buildings and structures. Those opportunities will certainly be better if the builder's relations with neighbours are good and if the builder convinces them that the risk to their property will be reduced during construction by the provision of such information. In this case, there is a need for effective communication with neighbours in order to avoid frightening them about possible risks. Lack of communication is due to the fact that everyone treats risk differently [19]. 
The selected technological processes of construction can determine the level of risks. From a geotechnical point of view, efficient technological processes can increase risks on the construction site. For example, hammering or vibrating a sheet pile wall results in producing dynamic effects that will lead to the occurrence of thixotropic processes, the soil will dissolve, and the surrounding structures may lose their foundations in silty sand saturated with water. Therefore, at the engineering feasibility stage, one of the essential tasks is to select the most appropriate technological processes taking into account the risks involved.

The risks of the construction project have to be assessed at all stages of its development. Each of these stages addresses different problems of risk manageability [20]. Figure 2 shows a diagram describing the risks under consideration during the stages of developing a geotechnical project. Risk identification and analysis is a continuous process, because each of the steps may result in additional data that will reveal new risks. The earlier the risk is identified, the easier its management will be.

To solve geotechnical problems, as the first step, the designer has to collect as much information as possible about the site itself and about the immediate environment that can affect the building being designed. This will allow potential risks to be assessed at the initial stages of the project (planning stage and engineering feasibility stage). Based on the analysis of the initial information, the project manager will also be able to decide on the extent of the required geotechnical exploration for the planned facility.

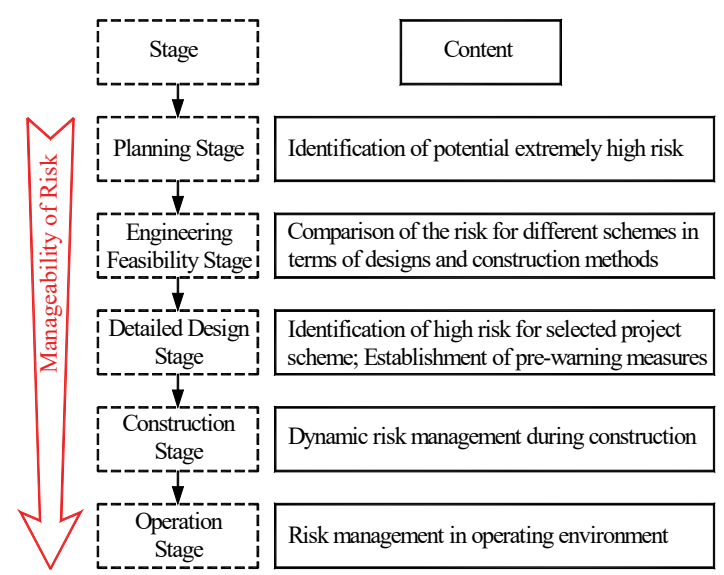

Figure 2 - Scheme for lifetime risk assessment by Huang and Zhang [20].

In different Member States of the European Union, investigation volumes are subject to the geotechnical category assigned to the object. This can be done using the process shown in Figure 3.

Subject to the category, the investigation volume and methods are regulated. A few geotechnical categories may form the object, which will depend on conditions for variations in the site and design constructions. It should also be considered that the situation must be monitored to determine whether there is a need to adjust the established geotechnical category during the whole construction process [22]. 


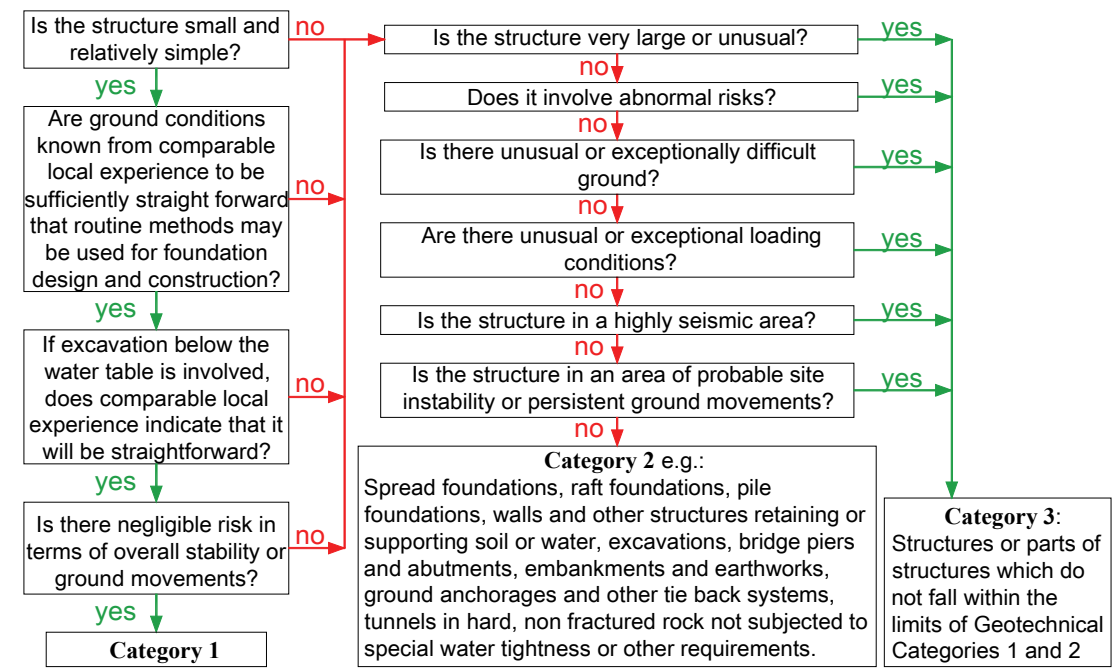

Figure 3 - The general decision tree for selecting a geotechnical category by Simpson and Driscoll [21].

However, even following recommendations can reveal some uncertainties. As a rule, for the objects of the second and third geotechnical categories, the mechanical properties of the soil are determined by laboratory tests. For example, in determining the indicators of the shear strength of the soil, their magnitude is subject to available comparable experience (see Table 3), according to EN 1997-2 [23]. Yet documents do not provide information on the type of comparable experience.

Table 3 - Direct shear test. The recommended minimum number of tests for one soil stratum [23].

\begin{tabular}{l|c|c|c}
\hline \multicolumn{3}{c}{ Recommended number of tests ${ }^{\mathrm{a}}$} \\
\hline Variability in strength envelope & \multicolumn{3}{|c}{ Comparable experience } \\
\cline { 2 - 4 } Coefficient of correlation on regression curve & None & Medium & Extensive \\
Coefficient of correlation $<0.95$ & 4 & 3 & 2 \\
$0.95 \leq$ coefficient of correlation $<0.98$ & 3 & 2 & 2 \\
Coefficient of correlation $\geq 0.98$ & 2 & 2 & $1^{\mathrm{b}}$ \\
\hline${ }^{\mathrm{a}}$ One recommended test means a set of three individual specimens tested at different normal \\
stresses. \\
b A single test and classification tests to verify compatibility with comparable experience. If the \\
test results do not agree with the existing data, additional tests should be run. \\
\hline
\end{tabular}

To identify geotechnical risk, specific geotechnical issues that are not always successfully solved by referring to regulatory documents about this particular field of construction need 
to be considered. Extensive experience of the parties involved in construction has to be taken into account. Thus, Chapter 3 applies the face-to-face interview approach followed by the construction participants analysing a certain case study and identifying the main problems using a cause and effect diagram.

\section{RISK IDENTIFICATION APPLYING THE FACE-TO-FACE INTERVIEW APPROACH}

\subsection{Data Collection}

The authors of this article mainly focus on identifying risks arising from the installation of a flexible retaining wall. Thus, to achieve this goal, the face-to-face interview approach, which is one of the methods recommended by ISO / IEC 31010: 2009 [24] was preferred, based on the argument that it has a lower non-response rate than other methods of surveying.

Furthermore, compared to other cases, the questioning technique enhances the opportunity to obtain more information and reduces the amount of time required to obtain the information. The face-to-face interview approach, being flexible, allows data collection using strictly structured to unstructured questions and very short to long answers [25].

The authors of this article conducted face-to-face interviews of 14 respondents with no time limit; each interview lasted approximately 30-50 minutes. All of the interviews were administered by the same person, who had 22 years of work experience in the field of designing geotechnical structures.

The types of experiences of the respondents and length of experience in their present positions and in total are listed in Table 4, below.

Table 4 - The demographics of the participants

\begin{tabular}{cccc}
\hline Respondent & Type of Professional Experience & $\begin{array}{c}\text { Experience in the } \\
\text { present position } \\
\text { (years) }\end{array}$ & $\begin{array}{c}\text { Experience in } \\
\text { total } \\
\text { (years) }\end{array}$ \\
\hline 1 & Associate Professor & 37 & 37 \\
2 & Associate Professor & 8 & 12 \\
3 & Architect & 5 & 13 \\
4 & Geotechnical Designer & 7 & 17 \\
5 & Geotechnical Designer & 3 & 3 \\
6 & Geotechnical Designer & 10 & 10 \\
7 & Geotechnical Expert & 24 & 40 \\
8 & Structural Designer - Structural & 15 & 20 \\
9 & Project Manager (SPM) & & 13 \\
\hline
\end{tabular}


Table 4 - The demographics of the participants (continue)

\begin{tabular}{cccc}
\hline Respondent & Type of Professional Experience & $\begin{array}{c}\text { Experience in the } \\
\text { present position } \\
\text { (years) }\end{array}$ & $\begin{array}{c}\text { Experience in } \\
\text { total } \\
\text { (years) }\end{array}$ \\
\hline 10 & $\begin{array}{c}\text { Structural Designer }- \text { Structural } \\
\text { Project Manager (SPM) } \\
\text { Structural Designer }- \text { Structural } \\
\text { Project Manager (SPM) } \\
\text { Structural Designer }- \text { Structural } \\
\text { Project Manager (SPM) } \\
\text { Expert in Maintenance } \\
\text { Construction Manager }\end{array}$ & 10 & 19 \\
12 & 8 & 8 & 16 \\
14 & & 15 & 12 \\
\hline
\end{tabular}

The interviewees were asked to list the types of geotechnical structures they designed based on the frequency and level of contribution of their experience.

In response to this enquiry, the top three types of geotechnical structures designed were revealed to be pile foundations (30\%), retaining walls (26\%), and shallow foundations $(23 \%)$. The distribution of the geotechnical structures designed by the respondents is as depicted in Figure 4.

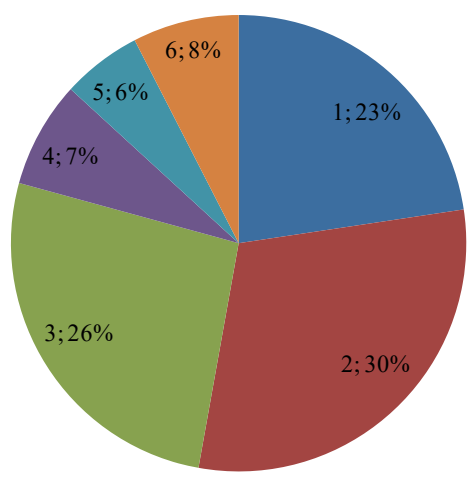

Figure 4 - Geotechnical structures most frequently designed by the respondents:

1 - shallow foundations; 2 - pile foundations; 3 - retaining walls; 4 - excavations, slopes, dikes; 5 - anchors; 6 - other types of geotechnical structures (floor, foundation underpinning, roads, collectors).

As can be seen from Figure 4, the most commonly used structure is pile foundations and the second choice is retaining walls.

The most commonly encountered problems identified by the respondents were related to retaining walls, loose soil, and water. However, very often, respondents related these problems to insufficient geological exploration, limited information about surrounding structures and engineering infrastructure, and their assessment at all stages of construction. 
It is worth noting that underground barriers were mentioned as problems only by geotechnical engineers. The frequency of problems encountered in geotechnical structures as reported by the respondents is given in Figure 5.

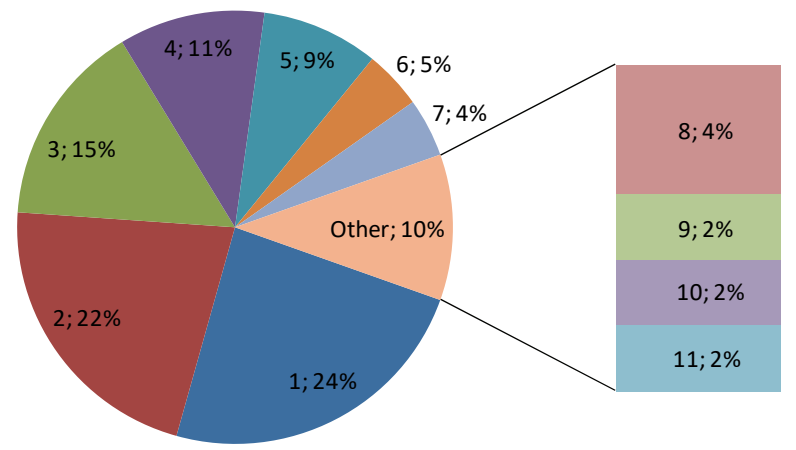

Figure 5 - Frequency of problems encountered related to:

1 - retaining walls; 2 - loose soil; 3 -water; 4 - limited information about surrounding structures and engineering networks; 5 - small number ground test; 6 - shallow foundations; 7 - foundation underpinning; 8 - dynamic loading; 9 - underground barriers; 10 - interaction between geotechnical and overhead structures; 11 - overall stability.

When answering the questions about quality mismatches specific to geotechnical structures and the usual reasons for their occurrence, 10 out of 14 respondents identified quality mismatch as a deviation inherent in geotechnical structures. Others mentioned sediment, insecure reinforcement in the project, insufficient depth, inadequate waterproofing, and concrete works.

The most significant reason for the appearance of poor-quality geotechnical structures, according to the respondents, was the geological conditions and their poor assessment or insufficient geological explorations. Workplace culture on the construction site and errors in design took second position. Errors in design were often (two times out of four) related to the inadequacies of technological processes with computational schemes. Also, tight work deadlines, incorrectly applied technology, misunderstandings, and corruption were also pointed out. The reasons for poor quality of the finished work and their respective weights are shown in Figure 6.

Insufficiency of geological and engineering investigations was cited as the most common cause of poor-quality work. Therefore, an additional enquiry was carried out with the aim of determining the causes of and reasons for complementary investigations in the design and construction stages. Only 11 of 14 interviewees responded to this line of enquiry: three respondents carried out the exploration when the properties of the soil at the site at the time of construction did not match the data provided in the report; six respondents did so when they lacked data in the design stage (insufficient depth of exploration, unspecified mechanical properties of the soil, filtration coefficient, etc.); two of them commissioned additional studies to clarify the characteristics of the loose soil for a reliable and cost effective design (Figure 7). 
Geotechnical Risk Identification: Case Study of Flexible Retaining Walls Installation

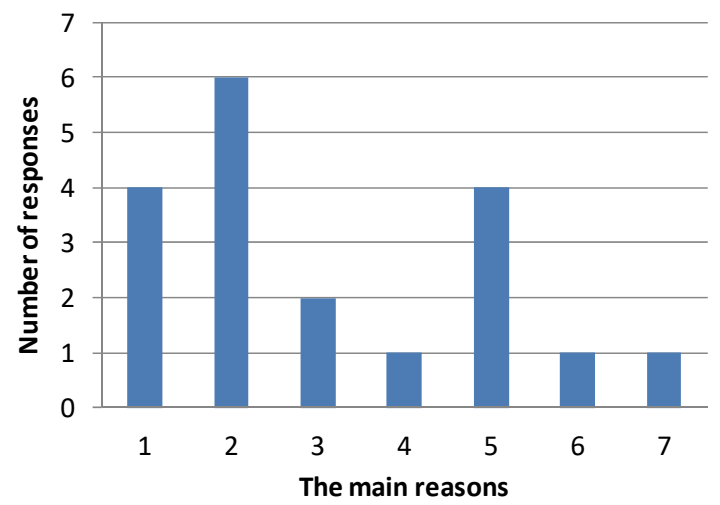

Figure 6 - The main reasons for low-quality geotechnical structures:

1 - workplace culture; 2 - geological conditions or poor evaluation of geological conditions; 3 - busy work schedules; 4 - incorrect application of technology; 5 - errors in design; 6 - misunderstandings; 7 - corruption.

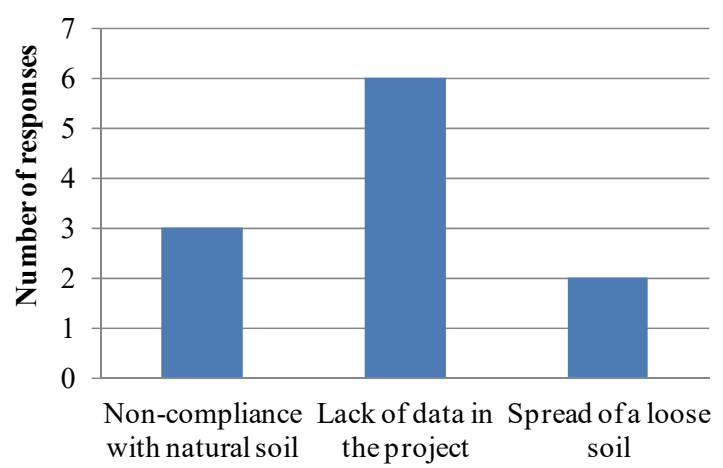

Figure 7 - Reasons for conducting additional geological and engineering investigations.

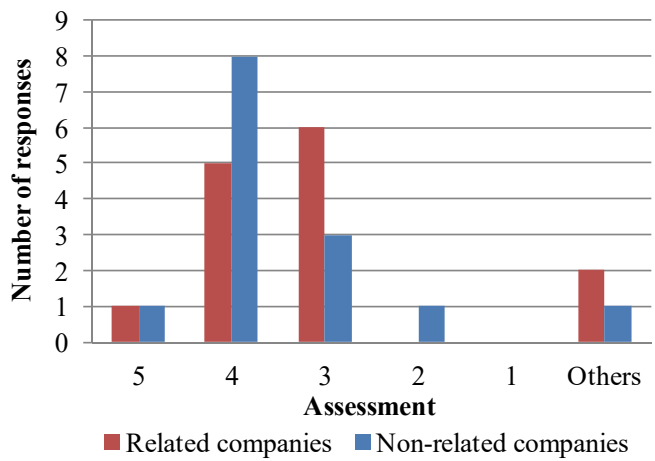

Figure 8 - Confidence in the experts 
Geotechnical experts are frequently invited to participate at all stages of construction; however, the effectiveness of these sessions depends on the mutual trust between construction participants. Thus, the respondents were asked to assess their confidence in the experts, specifically confidence in experts from related companies and those from unrelated companies, that is, outsiders. Respondents were asked to rank their confidence levels using a 1 to 5 scale where 1 means 'no trust at all' and 5 means 'trust blindly and do not check the statements made'. The outcome of this enquiry is shown in Figure 8.

All respondents felt more confident when experts were independent, because they could more objectively assess the situation without 'linking' their opinions to a particular solution or the solutions of a particular company.

As 'other' answers, two options were distinguished:

- in the first option, regardless of the considered issue being discussed with the expert company, the experts were evaluated on an individual basis from 1 to 4 subject to the company and the designer;

- the second option was related to the companies: 1 to 3 (depending on the situation whether a decision or requests made by the expert have an effect on the selection of a geotechnical company and a certain type of foundation).

The provided answers suggest (see Figure 8) that extreme degrees of confidence in experts are rare: total mistrust never occurred and absolute confidence was a rare occurrence.

\subsection{Geotechnical Risks of Installing Flexible Retaining Walls-Case Study}

This section analyses the geotechnical risks of installing flexible retaining walls. Flexible retaining walls started to be applied in residential construction in Lithuania approximately 20 years ago. This was due to growing demand for the creation of underground parking space in developed urban areas. Therefore, it is no coincidence that the flexible retaining wall appears as the most common problem-related geotechnical structure. During the last 10 years, two accidents involving soil excavation and retaining walls have occurred on construction sites in Lithuania.

The second part of the interview was dedicated to the geotechnical risk of the stages in the installation of flexible retaining walls. The enquiry was aimed at determining the risks involved and the consequences incurred.

Assessment of the construction practice of flexible retaining walls led to the identification of seven stages of construction (Tables 5-9):

- Stage 1 - driving an H-beam into the designed position;

- Stage 2 - first-level excavation;

- Stage 3 - installing an anchor;

- Stage 4 - excavation up to the designed position;

- Stage 5 - installing piles next to the wall;

- Stage 6-installing the first overlay;

- Stage 7 - installing the second overlay. 


\subsubsection{Interviews for the geotechnical risk of the steps in the installation of the flexible retaining wall}

The respondents were asked to assess the compliance of the calculation scheme with the technological one and to identify the relevance of the aforementioned risks, consequences, and likely conditions to be observed at each stage and to recommend preventive measures to be undertaken to mitigate the risks.

Analysis of the calculation schemes showed that only two respondents underlined that pressure tubes sometimes formed intermediate cast-in-place that should affect the calculations of flexible retaining walls. Therefore, it was necessary to assess whether the load from the pipe could affect the retaining wall at all stages. As for the other stages, half of the respondents pointed out the following:

- in Stages 2 and 4, the calculated depth of the excavation has to be taken into account when estimating the possible inaccuracies of the excavation rather than accepting a standard size;

- in Stage 5, cast-in-place formation opposite the wall destroys the foundation of the retaining wall and therefore it is necessary to estimate this in the calculation scheme (Figure 9).

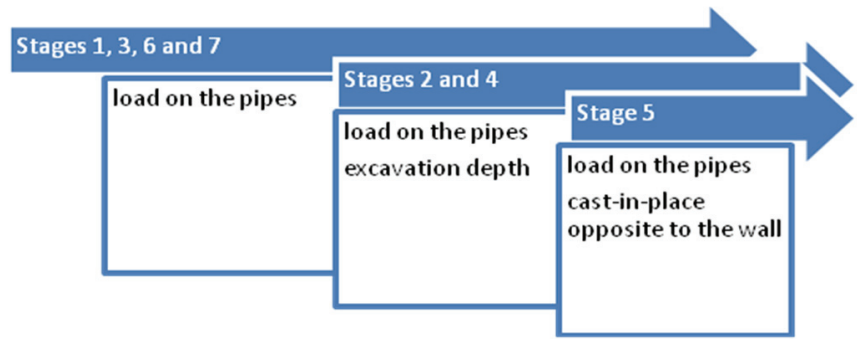

Figure 9 - Comments on the compliance of calculation schemes with technological schemes.

The tables below (Tables 5-9) show the summarized answers to the questions about risks arising and their consequences and conditions for the emergence of hazards occurring in each stage. The numbers in brackets next to the risks and conditions for risks indicate the number of respondents who named them.

The smallest number of risks were identified in Stages 6 and 7 (Table 5).

The most frequent ones involve the following:

- too-deep excavation (Stages 2 and 4, Tables 8 and 9);

- deviations from designed anchors and beam anchors or insufficient bearing capacity (Stage 3, Table 6);

- foundation weakening caused by anchor installation (Stage 5, Table 7);

- H-beam deepening and related risks (Stages 1 to 3, Tables 6 and 8). 
Table 5 - The analysis of risks, consequences, and conditions in the case study. Stages 6 and 7.

\begin{tabular}{|c|c|c|c|}
\hline \multicolumn{4}{|c|}{ Stage 6 - Installing the $1^{\text {st }}$ overlay } \\
\hline \multicolumn{2}{|r|}{$\begin{array}{l}\text { Scheme / risk of the } \\
\text { technological process }\end{array}$} & $\begin{array}{l}\text { Calculation scheme / } \\
\text { consequence }\end{array}$ & Description / conditions \\
\hline 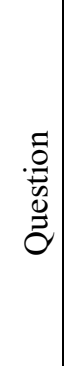 & & $-\mathrm{P}$ & $\begin{array}{l}\text { Concrete is poured on the grate, } \\
\text { wall and overlay above formed } \\
\text { cast-in-place } \\
\text { In } 28 \text { days after laying concrete, } \\
\text { temporary anchors are released }\end{array}$ \\
\hline \multirow{3}{*}{ 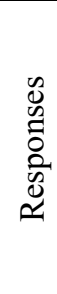 } & \multirow[t]{3}{*}{$\begin{array}{l}\text { Loosening anchors will } \\
\text { move the wall (3) }\end{array}$} & \multirow{3}{*}{$\begin{array}{l}\text { Collapse or deformations of } \\
\text { the retaining wall } \Rightarrow \text { crack } \\
\text { in the pipe }\end{array}$} & $\begin{array}{l}\text { Poor contact between the } \\
\text { overlay and retaining wall }(2)^{*}\end{array}$ \\
\hline & & & $\begin{array}{l}\text { Calculation scheme does not } \\
\text { correspond to the actual } \\
\text { situation of the overlay (1) }\end{array}$ \\
\hline & & & $\begin{array}{c}\text { Overlay design did not consider } \\
\text { horizontal loads }(2)\end{array}$ \\
\hline \multicolumn{4}{|c|}{ Stage 7 - Installing the $2^{\text {nd }}$ overlay } \\
\hline 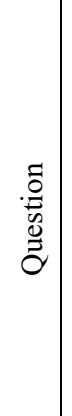 & & $\frac{t w+t}{3}$ & $\begin{array}{l}\text { Overlays are produced } \\
\text { following concrete hardening } \\
\text { (in } 28 \text { days after laying } \\
\text { concrete) } \\
\text { One-story wall is concreted }\end{array}$ \\
\hline 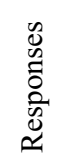 & $\begin{array}{c}\text { The overlay will not accept } \\
\text { horizontal loads (3) }\end{array}$ & $\begin{array}{l}\text { Collapse or deformations of } \\
\text { the retaining wall } \Rightarrow \text { crack } \\
\text { in the pipe }\end{array}$ & $\begin{array}{c}\text { Poor contact between the } \\
\text { overlay ( } 2 \text { ) and retaining wall } \\
\text { Overlay design did not consider } \\
\text { horizontal loads (1) }\end{array}$ \\
\hline & rackets next to risks and co & ons for risks indicate the nun & er of the respondents who name \\
\hline
\end{tabular}


The most common opinion about potential risk was obtained by analysing Stage 4; foundation weakening within the process of forming cast-in-place pile was identified as a risk (Table 9).

Table 6 - The analysis of risks, consequences, and conditions in the case study. Stage 3.

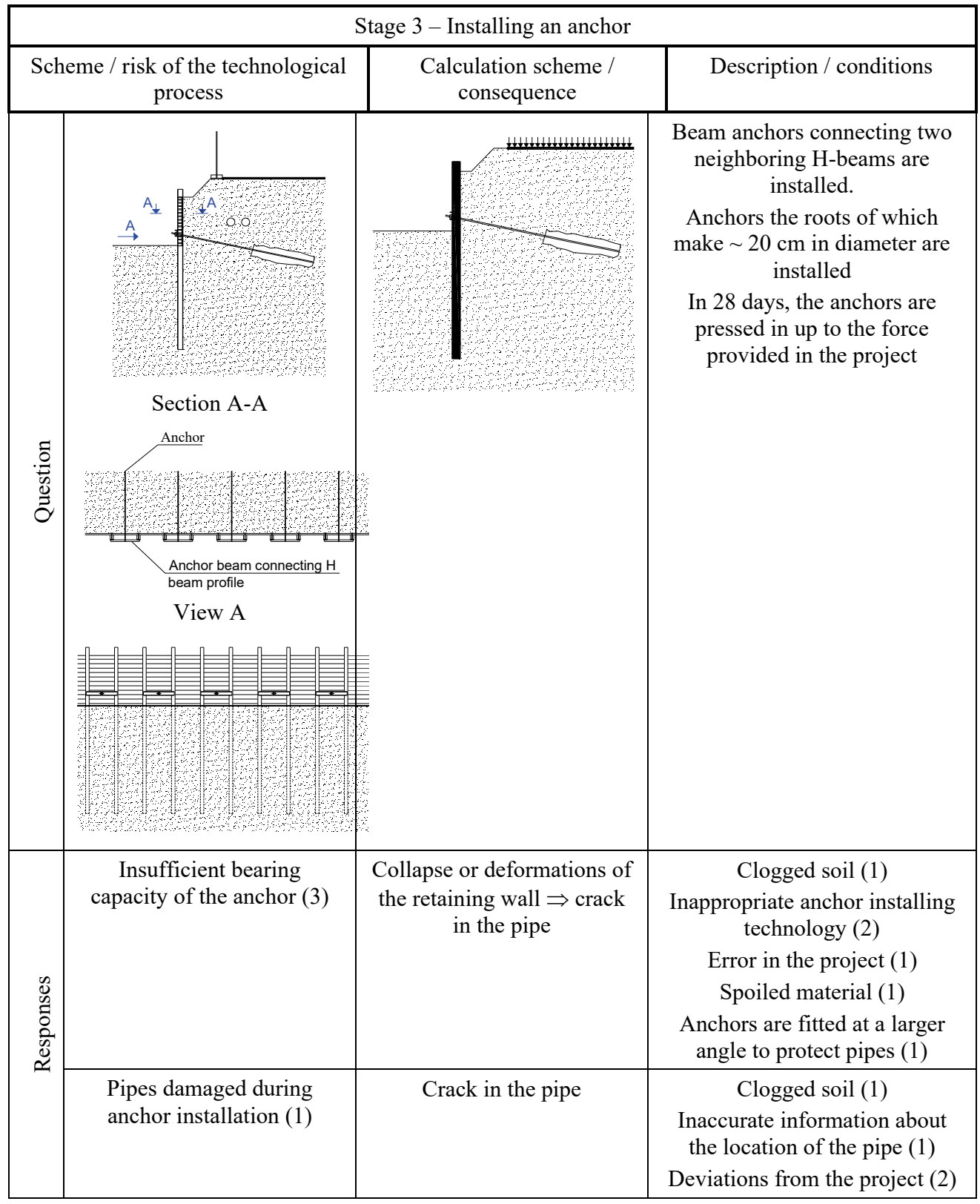




\begin{tabular}{|c|c|c|}
\hline $\begin{array}{c}\text { collapse of the beam anchor } \\
(5)\end{array}$ & $\begin{array}{c}\text { Collapse or deformations of } \\
\text { the retaining wall } \Rightarrow \text { crack } \\
\text { in the pipe }\end{array}$ & $\begin{array}{c}\text { Inappropriate anchor installing } \\
\text { technology (1) }\end{array}$ \\
\begin{tabular}{c|c} 
Deviations from installing H- \\
beams: distance are too large \\
$(2)$
\end{tabular} \\
$\begin{array}{c}\text { Too small profile of beam } \\
\text { anchors has been selected (3) } \\
\text { H-beams are interconnected } \\
\text { only in pairs not using a } \\
\text { continuous beam anchor } \\
\text { collapse of H-beams (2) }\end{array}$ & $\begin{array}{c}\text { Collapse or deformations of } \\
\text { the retaining wall } \Rightarrow \text { crack } \\
\text { in the pipe }\end{array}$ & $\begin{array}{c}\text { Looser soil than that found } \\
\text { during investigation (2) } \\
\text { H-beams are interconnected } \\
\text { only in pairs not using a } \\
\text { continuous beam anchor (5) }\end{array}$ \\
\hline
\end{tabular}

Table 7 - The analysis of risks, consequences, and conditions in the case study. Stage 5.

\begin{tabular}{|c|c|c|c|}
\hline \multicolumn{4}{|c|}{ Stage 5 - Installing piles next to the wall } \\
\hline Sche & $\begin{array}{l}\text { he / risk of the technological } \\
\text { process }\end{array}$ & $\begin{array}{l}\text { Calculation scheme / } \\
\text { consequence }\end{array}$ & Description / conditions \\
\hline $\begin{array}{l}\stackrel{\Xi}{0} \\
\stackrel{0}{0} \\
\stackrel{0}{\sigma}\end{array}$ & 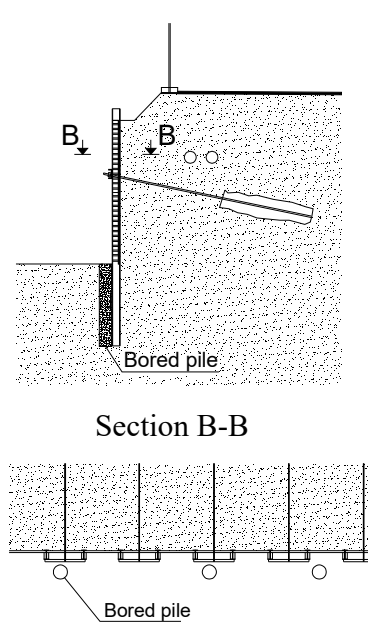 & $\begin{array}{l}\text { Calculations of the retention } \\
\text { walls of stage } 4 \text { are used }\end{array}$ & $\begin{array}{l}\text { Formed cast-in-place bearing } \\
\text { vertical loads of the retention } \\
\text { wall are erected }\end{array}$ \\
\hline $\begin{array}{l}0 \\
0 \\
0 \\
0 \\
0 \\
0 \\
2\end{array}$ & $\begin{array}{l}\text { The foundations opposite } \\
\text { the retention wall are } \\
\text { weakened (7) }\end{array}$ & $\begin{array}{l}\text { Collapse or deformations of } \\
\text { the retaining wall } \Rightarrow \text { crack } \\
\text { in the pipe }\end{array}$ & $\begin{array}{l}\text { Cast-in-place formation is very } \\
\text { close to the H-beam (2) } \\
\text { Inappropriate cast-in-place } \\
\text { formation technology, cast-in- } \\
\text { place forming weakens the } \\
\text { foundations (6) }\end{array}$ \\
\hline
\end{tabular}




\begin{tabular}{|l|l|c|}
\hline & $\begin{array}{c}\text { Loss of overall stability } \\
\text { crack in the pipe }\end{array}$ & $\begin{array}{c}\text { Cast-in-place formation is very } \\
\text { close to the H-beam (2) } \\
\text { Inappropriate cast-in-place } \\
\text { formation technology, cast-in- } \\
\text { place formation weakens the } \\
\text { foundations (6) }\end{array}$ \\
\hline
\end{tabular}

Table 8 - The analysis of risks, consequences, and conditions in the case study. Stages 1 and 2 .

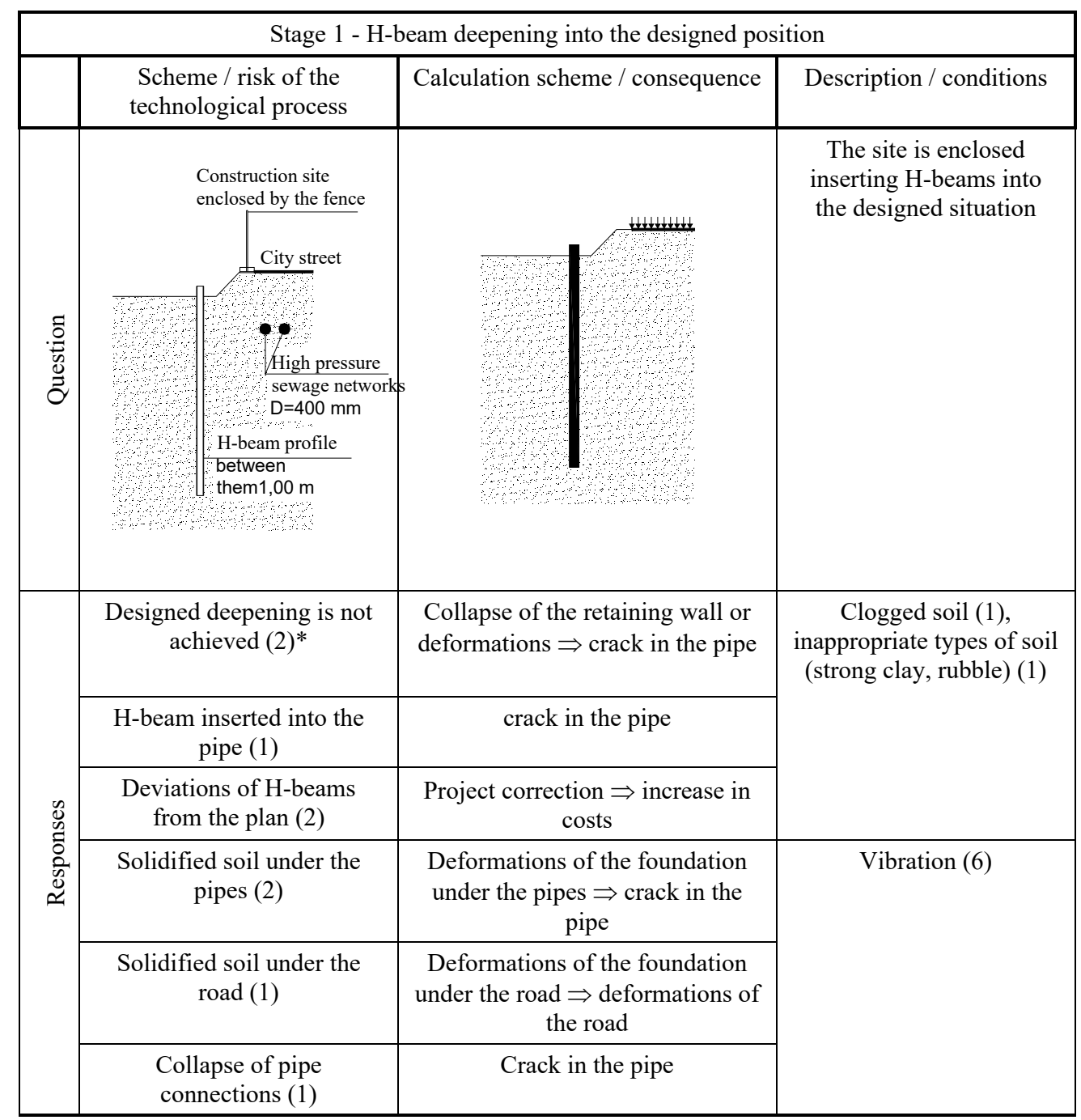




\begin{tabular}{|c|c|c|c|}
\hline \multicolumn{4}{|c|}{ Stage $2-1$ st level excavation } \\
\hline 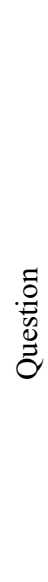 & 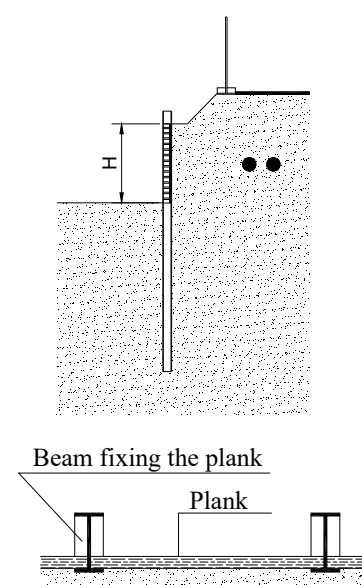 & 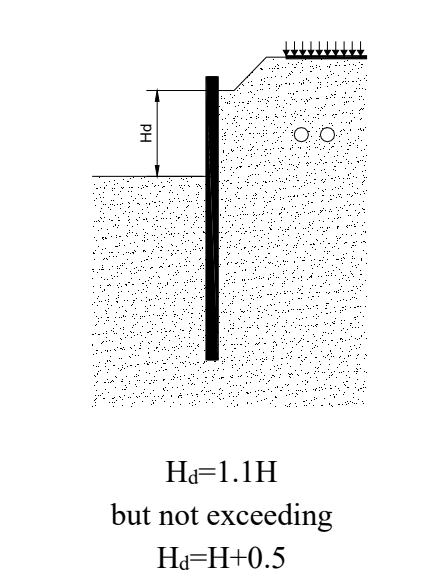 & $\begin{array}{l}\text { Level } 1 \text { is excavated to be } \\
\text { fitted with anchors } \\
\text { To prevent sand } \\
\text { crumbling, planks are } \\
\text { embedded between H- } \\
\text { beams }\end{array}$ \\
\hline \multirow{5}{*}{ 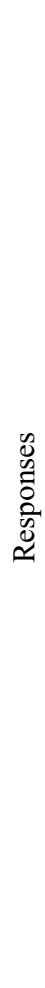 } & $\begin{array}{l}\text { Cavities form between } \\
\text { planks and soil matter form } \\
\text { (2) }\end{array}$ & $\begin{array}{l}\text { Soil moves behind the retaining } \\
\text { wall } \Rightarrow \text { deformations of pipe } \\
\text { foundations } \Rightarrow \text { crack in the pipe }\end{array}$ & $\begin{array}{l}\text { Crumbly, dry soil, } \\
\text { recommendations are } \\
\text { neglected when work is } \\
\text { done' (3) }\end{array}$ \\
\hline & $\begin{array}{l}\text { Larger load than that } \\
\text { expected in the road zone } \\
\text { (1) }\end{array}$ & $\begin{array}{l}\text { Collapse or deformations of the } \\
\text { retaining wall } \Rightarrow \text { crack in the pipe }\end{array}$ & $\begin{array}{l}\text { The project does not } \\
\text { provide the possibility of } \\
\text { carrying heavy loads, } \\
\text { transport weight is not } \\
\text { limited (1) }\end{array}$ \\
\hline & $\begin{array}{c}\text { Separate H-beams can enter } \\
\text { the layer of the unexpected } \\
\text { looser soil } \\
\text { (3) }\end{array}$ & $\begin{array}{l}\text { Collapse or deformations of the } \\
\text { retaining wall } \Rightarrow \text { crack in the pipe }\end{array}$ & $\begin{array}{l}\text { H-beams are not } \\
\text { interconnected, } \\
\text { insufficient soil } \\
\text { investigation (4) }\end{array}$ \\
\hline & Planks break (2) & $\begin{array}{l}\text { Soil moves behind the retaining } \\
\text { wall } \Rightarrow \text { deformations of pipe } \\
\text { foundations } \Rightarrow \text { crack in the pipe }\end{array}$ & $\begin{array}{l}\text { Distances between } \mathrm{H}- \\
\text { beams are larger than } \\
\text { those provided in the } \\
\text { project (2) } \\
\text { Heavier load acting on the } \\
\text { planks than that provided } \\
\text { in the project (3) }\end{array}$ \\
\hline & $\begin{array}{l}\text { The excavation is deeper } \\
\text { than that provided in the } \\
\text { calculation scheme (4) }\end{array}$ & $\begin{array}{l}\text { Collapse or deformations of the } \\
\text { retaining wall } \Rightarrow \text { crack in the pipe }\end{array}$ & $\begin{array}{l}\text { Improper control during } \\
\text { construction (1) } \\
\text { Misunderstandings } \\
\text { between the construction } \\
\text { parties (5) }\end{array}$ \\
\hline
\end{tabular}


Table 9 - The analysis of risks, consequences, and conditions in the case study. Stage 4.

\begin{tabular}{|c|c|c|}
\hline \multicolumn{3}{|c|}{ Stage 4 - Excavation up to the designed position } \\
\hline $\begin{array}{l}\text { Scheme / risk of the } \\
\text { technological process }\end{array}$ & $\begin{array}{c}\text { Calculation scheme / } \\
\text { consequence }\end{array}$ & Description / conditions \\
\hline 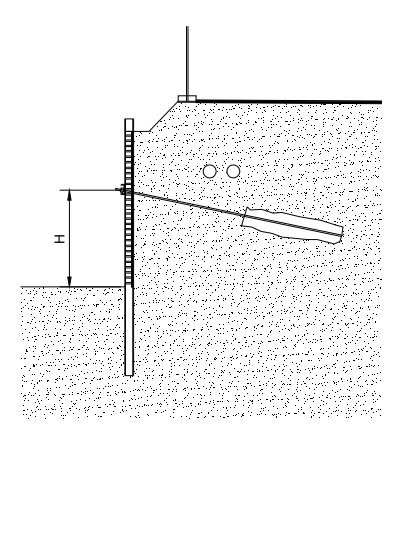 & $\begin{array}{c}\mathrm{Hd}=1.1 \mathrm{H} \\
\text { but not exceeding } \\
\mathrm{Hd}=\mathrm{H}+0.5 \mathrm{~m}\end{array}$ & $\begin{array}{c}\text { Excavated up to the altitude } \\
\text { of the designed foundation } \\
\text { pit }\end{array}$ \\
\hline $\begin{array}{l}\text { Excavation is deeper than that } \\
\text { provided in the computation } \\
\text { scheme (5) }\end{array}$ & $\begin{array}{c}\text { Collapse or deformations of the } \\
\text { retaining wall } \Rightarrow \text { crack in the } \\
\text { pipe }\end{array}$ & $\begin{array}{l}\text { Improper control during } \\
\text { construction (5) } \\
\text { Misunderstandings between } \\
\text { the parties of construction } \\
\text { (2) }\end{array}$ \\
\hline Loss of overall stability (2) & $\begin{array}{c}\text { Collapse or deformations of the } \\
\text { retaining wall } \Rightarrow \text { crack in the } \\
\text { pipe }\end{array}$ & $\begin{array}{c}\text { Too short anchors }(1) \\
\text { Anchors are installed at a } \\
\text { sharper angle of inclination } \\
\text { than that provided in } \\
\text { calculations (1) } \\
\text { Overall stability is not } \\
\text { verified (1) }\end{array}$ \\
\hline
\end{tabular}

On requesting recommendations regarding preventive measures that could be taken to reduce risks, experts' comments regarding all the design and construction stages of the retention wall involved remarks indicating that having a detailed project and sufficient time to prepare it, the collection of sufficient data on the environment and geological conditions, permanent structural monitoring, and close cooperation between all construction participants are the aspects that have a powerful effect on work quality and the reduction of errors. Reducing or eliminating pressure to decrease stress in the pipes was mentioned as a specific requirement for this structure during construction.

Additional preventive measures distinguished by stages are as follows:

Stage 1 includes the application of other technology for the installation of the retention wall, maintaining a safe distance to the pipes, conducting geotechnical studies of sufficient scope, and collecting a substantial amount of relevant data on the location and condition of the pipes. 
Stage 2 covers control of the depth of the excavation and the careful installation of planks to minimize soil crumbling.

Stage 3 involves the process of making a continuous beam anchor that integrates H-beams and anchors into the common system; all anchors must be tightened and tested in accordance with the requirements for normative documents, the depth of the pipelines must be adjusted, a sufficient distance from the borehole for the anchor to the bottom of the pipeline must be maintained, the drilling angle must be monitored, and the designed injection area must be as far as possible beyond the pipelines.

Stage 4 keeps control of the excavation.

Stage 5 embraces the selection of cast-in-place formation technology that should minimally damage the foundations of H-beams and form cast-in-place as far from the H-beams as possible. The stage also points to forming cast-in-place with pauses to reduce temporarily weakened areas.

The interview was informal and had no time limit. Although the face-to-face interview approach was used and assisted in clarifying the situation, there was no respondent who should focus on all the risks listed in the table.

One of the respondent designers (Structural Project Manager) described situations and calculation schemes as logical and thoughtful and therefore did not face any risks in the process of installing flexible retaining walls. The surveyed architect, project manager (PM) distinguished only deviations from the design situation as risks that could affect architectural decisions.

The respondents agreed with the opinion that the greatest loss in the given situation would be caused by a breakdown in the pressure pipe and pollution of the natural environment by wastewater. Also, breakdown in the pressure pipe was mainly mentioned when assessing the final consequences of the risk.

\subsubsection{Drawing the Cause and Effect Diagram}

One of the major outcomes identified in the interviews was breakdown in the pressure pipe, which would lead to the greatest loss. After scrutiny of the data obtained from the interviews, to further clarify the possible causes of breakdown of the pressure pipe, a brainstorming session was held. Five experts who cited the majority of risks during interviews (one geotechnical expert, one designer (Structural Project Manager), two geotechnical designers, and one construction manager) were selected as participants. First, the participants were briefed about the case of breakdown of the pipes, and six categories of causes, namely technology, time, management, environment, people, and structures (geotechnology), were identified. Then they were asked to come up with as many causes of such an incident as possible. Finally, all the possible causes cited for the breakdown of the pressure pipe (the effect) were used to construct the cause and effect diagram (see Figure 10). The findings are summarized below:

Structural-geotechnical causes

- structural members of retention walls (H-beams, soil-retention planks, anchors);

- technological processes related to the installation and testing of structural members (vibration, cast-in-place formation opposite the retention wall technology); 
- pit excavation (information included in the project, match with the calculation scheme, control over altitudes);

- initial information and the project (geological and engineering investigations, the place of the pipes in space, project finalization and application of technology used, the accuracy of calculation schemes, the amount and accuracy of all information).

Environmental causes

- accuracy and content of geological and engineering investigations;

- information on the surrounding buildings and structures;

- loads and impacts (e.g. transport, seismic, technological).

Technological causes

- technologies used in the construction of structures and their negative effects on the structures or their members.

Managerial causes

- poor organization;

- frequent changes in projects;

- excessive workloads;

- insufficient experience of installing BIM systems.

Time-related causes

- busy work schedules that disregard technologies.

Staff-related reasons:

- poor communication between stakeholders;

- lack of staff;

- errors in taking control of the project;

- errors in developing the geotechnical project.

Brainstorming disclosed that answers to the question of 'why it might happen' were based on:

- experience gained in the individual's and company's projects or acquired by analysing past failures in other projects;

- theoretical knowledge obtained during studies or on training courses;

- directions provided by regulatory documentation describing investigation, design, and installation.

Although the aim of the participants was to identify the risks of installing retaining walls and determining their causes while placing major focus on the retention wall as a geotechnical structure, other causes of risks related to technology, time, management, environment, and human resources were identified too. The selected team has to ensure the representation of all stakeholders and participants of construction- the composition of the team needs to be adjusted according to the intended goals. In this way, the project can be analysed in more detail.

Based on these observations, one can conclude that the proper selection of brainstorming participants can lead to good results when analysing geotechnical structures with respect to risks. 


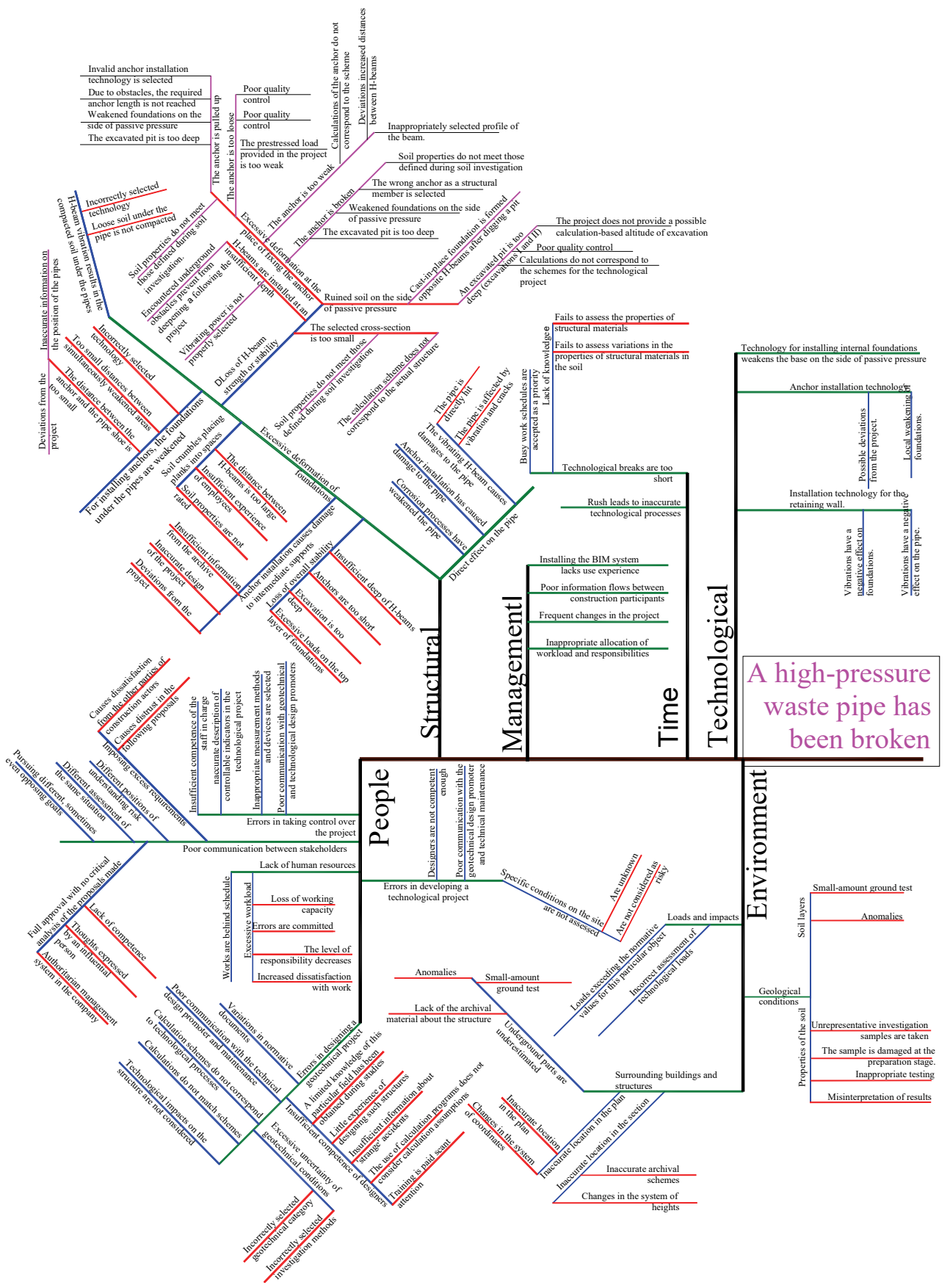

Figure 10 - The cause and effect diagram according to the information collected during brainstorming. 


\section{DISCUSSION}

Based on the analysis carried out, the authors of the paper proposed risk identification of flexible retaining walls using a risk management flow based on Mishra et al. [8] and ISO/IEC 31010:2009 [24]. In the future, this chart (Figure 11) can be verified by analysing other geotechnical structures. For the effective application of risk identification in flexible retaining wall risk management flow, a well-prepared team representing all interested parties should be created.

Data collected on the investigated structure. A detailed project, including calculation schemes, descriptions of technology, and the work order, is developed, and all information on adjacent buildings and structures and data of geological engineering exploration are obtained.

The collected information assists in establishing the content, thus allowing the risk management objectives, criteria, and assessment programme to be identified and coordinated. If the required information is missing, data are added before proceeding to the next stage.

The purpose of risk assessment is to help make decisions based on the results of risk analysis, define the risks to be reduced, and set risk reduction priorities. Risk assessment includes one or a few options for changing risk and implementing these options.

First, the risks are identified, which involves all pre-selected construction participants and interested persons, for example, by applying the face-to-face interview approach. Brainstorming is used to identify risks. To facilitate risk management, the installation of the flexible retaining wall should be divided into technological stages.

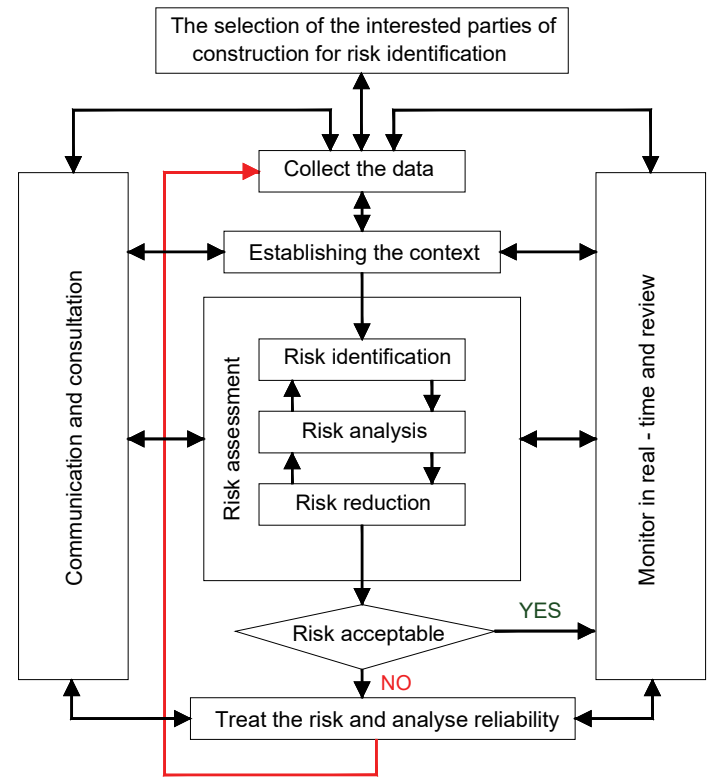

Figure 11 - Risk identification in flexible retaining wall risk management flow according to ISO/IEC 31010:2009 [24] and Mishra et al. [8] 
At the stage of risk analysis, the probability of occurrence of the appropriate type of risk is estimated. The consequences established at the risk identification stage are also assessed; that is, their impact on the project and its related activities is evaluated.

The stage of selecting preventive measures, reducing risk, and analysing the reduced risk completes the risk assessment. Thus, the question of 'whether the risk is acceptable' arises.

The authors of the article propose that if the risk is not acceptable, the data collection stage should be performed again to acquire new data. It may involve material for additional geological engineering exploration or any other bonus information that may affect the risk of installing the retaining wall. Then, everything is repeated again. At the risk assessment stage, the processes of risk identification, analysis, and reduction are very closely interrelated and therefore have to complement one other.

The participants must be involved in information exchange, tutorials, risk monitoring, and review within the whole process. In order to identify risk, first of all, the selection of all construction participants involved has to be made. They may analyse geotechnical risks and related problems. The proposal is based on the analysis carried out in this article and on the observation that not all construction participants having experience in the field of construction - are able to identify geotechnical risk (see Section 3).

\section{CONCLUSIONS}

Analysis of the scientific literature with reference to the topic of the article shows that the risk of collapse or deformations of flexible retaining walls has not been widely analysed.

In order to determine the risk of installing flexible retaining walls, the authors of the article used the face-to-face interview approach, brainstorming, and a cause and effect diagram. A specific case study is presented.

The examination of the specific case (interviewing) demonstrated that the respondents identified risks and proposed additional preventive measures. The respondents expressed the same opinion about the given situation and agreed that the greatest loss would be caused by breakdown of the pressure pipe and pollution of the natural environment with wastewater. Also, breakdown in the pressure pipe was the most frequently mentioned option when assessing the final consequences of risks.

Investigation of the data obtained during the face-to-face interview was based on brainstorming and the cause and effect diagram: five professionals who had monitored most of the risks were selected with the help of the face-to-face interview. The thoughts expressed during brainstorming were used as the basis for drawing the cause and effect diagram.

The study found that the face-to-face interview approach could only be applied to risk identification in simple cases and was suitable for preliminary screening of the respondents involved in brainstorming. Thus, the face-to-face interview approach should provide an identical or similar situation in order to independently assess the competence of would-be respondents considering a particular issue. 
Geotechnical experts are more trusted than other construction participants when expressing their positions on objects not related to it or the company that employs them. Cooperation is also smoother if reasoned statements are made.

\section{Acknowledgements}

We express our sincere gratitude to our colleagues who have been willing to discuss the ideas and who made comments at the early stage of development of this paper.

\section{Conflicts of Interest}

The authors declare no conflict of interest.

\section{References}

[1] Lacasse, S. Hazard, Reliability and risk assessment - research and practice for increased safety. NGM 2016 Reykjavik Proceedings. Paper presented at the 17th Nordic Geotechnical Meeting. Challenges in Nordic Geotechnics, 25-28 May 2016.

[2] Flage, R., Aven, T. Emerging risk - Conceptual definition and relation to black swan type of events. Reliab. Eng. Syst. Safe., 144, 61-67, 2015.

[3] ISO 31000:2009(E). Risk management - Principles and guidelines.

[4] Duncan, J.M. Factors of safety and reliability in geotechnical engineering. J. Geotech. Geoenviron., 126(4), 307-316, 2000.

[5] Gibson, W. Probabilistic methods for slope analysis and design. Aust. Geomech. J., 46(3), 1-12, 2011.

[6] Brown, E.T. Risk assessment and management in underground rock engineering - an overview. J. Rock Mech. Geotech. Eng, 4(3), 193-204, 2012.

[7] Swannell, N., Palmer, M., Barla, G., Barla, M. Geotechnical risk management approach for TBM tunnelling in squeezing ground conditions. Tunn. Undergr. Sp. Tech., 57, 201-210, 2016.

[8] Mishra, R.K., Janiszewski, M., Uotinen, L.K.T., Szydlowska, M., Siren, T., Rinne, M. Geotechnical Risk Management Concept for Intelligent Deep Mines, Procedia Eng, 191, 361-368, 2017.

[9] Xia, Y., Xiong Z., Dong, X., Lu, H. Risk assessment and decision-making under uncertainty in tunnel and underground engineering. Entropy, 19(10), 549, 2017.

[10] Haddad, A., Eidgahee, D.R., Naderpour, H. A probabilistic study on the geometrical design of gravity retaining walls. World J. Eng., 14(5), 414-422, 2017.

[11] Zou, Y., Kiviniemi, A., Jones, S.W. A review of risk management through BIM and BIM-related technologies. Safety Sci., 97, 88-98, 2017. 
[12] Li, Z., Xue, Y., Qiu, D., Xu, Z., Zhang, X., Zhou, B., Wang, X. AHP-ideal point model for large underground petroleum storage site selection: an engineering application. Sustainability, 9(12), 2343, 2017.

[13] Xue, Y., Cao, Z., Du, F., Zhu, L. The influence of the backfilling roadway driving sequence on the rockburst risk of a coal pillar based on an energy density criterion. Sustainability, 10(8), 2609, 2018.

[14] Ahmadi, M.; Behzadian, K.; Ardeshir, A.; Kapelan, Z. Comprehensive Risk Management Using Fuzzy FMEA and MCDA Techniques in Highway Construction Projects. Journal of Civil Engineering and Management 2017, 23 (2), 300-310, DOI: 10.3846/13923730.2015.1068847.

[15] Valipour, A.; Yahaya, N.; Md Noor, N.; Antuchevičienė, J.; Tamošaitienė, J. Hybrid SWARA-COPRAS Method for Risk Assessment in Deep Foundation Excavation Project: An Iranian Case Study. Journal of Civil Engineering and Management2017, 23(4), 524-532, DOI: https://doi.org/10.3846/13923730.2017.1281842

[16] SGF (Swedish Geotechnical Society). Risk Management in Geotechnical Engineering Projects-Requirements: Methodology. Report 1:2014E. 2nd ed. Linköping: Swedish Geotechnical $\quad$ Society. $2017 . \quad$ Available online: http://www.sgf.net/web/page.aspx?refid=4567 (accessed on 5 March 2018).

[17] Clayton, C.R.I. (ed.) Managing Geotechnical Risk - Improving Productivity in the United Kingdom, 2001.

[18] Baynes, F.J. Sources of geotechnical risk. Q. J. Eng. Geol. Hydrog., 43, 321-331, 2010.

[19] Sartain, N., Mian, J., Free, M. Presenting uncertainty clearly: challenges in communicating geotechnical risk. Geotechnical Safety and Risk V, 739-751, 2015.

[20] Huang, H., Zhang, D. Quantitative geotechnical risk management for tunneling projects in China. Geotechnical Safety and Risk V, 61-75, 2015.

[21] Simpson B \& Driscoll R, Eurocode 7: A Commentary. CRC Ltd, Watford. 179 p, 1998.

[22] EN-1997-1 Eurocode 7: Geotechnical Design-Part 1: General Rules. 168 p.

[23] EN-1997-2 Eurocode 7 - Geotechnical Design - Part 2: Ground Investigation and Testing. $196 \mathrm{p}$.

[24] ISO/IEC 31010:2009. Risk Management - Risk Assessment Techniques. International Organization for Standardization, Geneva.

[25] Dikčius, V. Marketing Research. Theory and Practice. Vilnius, Lithuania, 187 p, 2003 [in Lithuanian]. 
